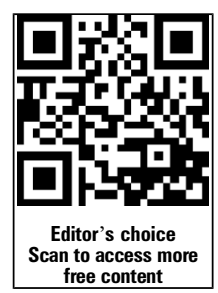

can to access mor content
free
- Additional material is published online only. To view please visit the journal online (http://dx.doi.org/10.1136/ oemed-2015-103336)

${ }^{1}$ MRC Lifecourse Epidemiology Unit, University of

Southampton, Southampton, UK

${ }^{2}$ Statistics and Epidemiology Unit, Science Directorate, Health and Safety Executive, UK

${ }^{3}$ Centre for Occupational and Environmental Health, University of Manchester, Manchester, UK

\section{Correspondence to} Professor David Coggon, MRC Lifecourse Epidemiology Unit, Southampton General Hospital, Southampton S016 6YD UK ; dnc@mrc.soton.ac.uk

Received 22 September 2015 Revised 5 February 2016 Accepted 2 March 2016 Published Online First 14 March 2016

\title{
Trends in mortality from occupational hazards among men in England and Wales during 1979-2010
}

\author{
E Clare Harris, ${ }^{1}$ Keith T Palmer, ${ }^{1}$ Vanessa Cox ${ }^{1}$ Andrew Darnton, ${ }^{2}$ John Osman, ${ }^{3}$ \\ David Coggon ${ }^{1}$
}

\section{ABSTRACT \\ Objectives To monitor the impact of health and safety provisions and inform future preventive strategies, we investigated trends in mortality from established occupational hazards in England and Wales.}

Methods We analysed data from death certificates on underlying cause of death and last full-time occupation for 3688916 deaths among men aged 20-74 years in England and Wales during 1979-2010 (excluding 1981 when records were incomplete). Proportional mortality ratios (PMRs), standardised for age and social class, were calculated for occupations at risk of specified hazards. Observed and expected numbers of deaths for each hazard were summed across occupations, and the differences summarised as average annual excesses. Results Excess mortality declined substantially for most hazards. For example, the annual excess of deaths from chronic bronchitis and emphysema fell from 170.7 during 1979-1990 to 36.0 in 2001-2010, and that for deaths from injury and poisoning from 237.0 to 87.5. In many cases, the improvements were associated with falling PMRs (suggesting safer working practices), but they also reflected reductions in the numbers of men employed in more hazardous jobs, and declining mortality from some diseases across the whole population. Notable exceptions to the general improvement were diseases caused by asbestos, especially in some construction trades and sinonasal cancer in woodworkers.

Conclusions The highest priority for future prevention of work-related fatalities is the minority of occupational disorders for which excess mortality remains static or is increasing, in particular asbestos-related disease among certain occupations in the construction industry and sinonasal cancer in woodworkers.

\section{INTRODUCTION}

Monitoring trends in the burden of illness and injury attributable to work is an important element in the control of occupational health hazards. ${ }^{1}$ It enables evaluation of the effectiveness of measures to reduce risk, and informs the prioritisation of future preventive strategies. The best methods for such monitoring vary according to the nature of the health outcome (eg, whether it is frequently fatal) and the confidence with which it can be ascribed to work in the individual case.

For some outcomes, the link to occupation can readily be established in the individual because they

\section{What this paper adds}

- It has been unclear to what extent improved working conditions in Britain over recent decades have reduced the burden of serious occupational disease, and which should now be the highest priorities for prevention.

- Analysis of data from death certificates indicates that during 1979-2010 excess mortality from most established occupational hazards declined substantially, most likely reflecting a combined effect of reduced employment in more hazardous jobs, improved health across the population as a whole, and safer working conditions.

- Notable exceptions to the general improvement are diseases caused by asbestos, especially in some construction trades and sinonasal cancer in woodworkers.

- Asbestos-related disease in the construction industry and sinonasal cancer in woodworkers remain priorities for future prevention of work-related mortality.

are specific to exposures in the workplace (eg, byssinosis, coal workers' pneumoconiosis), occur with very high relative risk in people who have undertaken certain jobs (eg, adenocarcinoma of the nose and nasal sinuses in furniture makers using hardwoods), or have distinctive clinical features when caused by work (eg, the temporal relationship of an injury to an occupational activity, demonstrable dermal sensitisation to an allergen encountered in the workplace). In these circumstances, the resultant burden can be assessed simply by counting attributable cases.

For other health outcomes, the relation to work is less specific, and cases that are caused by occupation are clinically indistinguishable from those that are not. For example, there are no distinctive clinical features of lung cancer that is caused by asbestos. In this situation, the attributable population burden can only be established epidemiologicallyby comparing risks in people with and without the relevant exposure. Estimates may be derived by direct assessment of attributable fractions in representative populations, or indirectly by applying estimates of relative risk from one source to data 
collected separately on the distribution of exposures in the population of interest.

National analyses of occupational mortality contribute importantly to this endeavour because they incorporate data on exposures and health outcomes for an entire population. They are particularly useful in the assessment of diseases and injuries with high fatality, but even where case fatality is lower, they may still provide helpful insights into trends over time, especially when there is little change in the proportion of cases that lead to death.

We have previously reported a national analysis of occupational mortality in England and Wales over two consecutive periods (1979-1990 and 1991-2000), ${ }^{2}$ and have now extended that investigation with addition of data from 2001 to 2010. Our aim was to evaluate trends across the three time periods in mortality from established occupational hazards, and the extent to which changes reflected altered levels of risk in relevant occupations as opposed to changes in the numbers at risk in those jobs, or an overall decline in mortality across all occupations (eg, because of improved medical care). Of particular interest was whether previously persistent excess mortality attributable to asbestos and wood dust ${ }^{2}$ had now started to fall.

\section{METHODS}

The analysis used data supplied by the Office for National Statistics (ONS) (previously the Office of Population Censuses and Surveys (OPCS)) on all deaths among men aged 2074 years in England and Wales during 1979-2010 (but excluding 1981 when records were incomplete). Information from death certificates on age at death, underlying cause of death and last full-time occupation was used to derive proportional mortality ratios (PMRs) with associated 95\% CIs for combinations of occupation and cause of death, the expected numbers being calculated with stratification by 5 -year age band and social class (determined from the last full-time occupation and classified to seven levels), taking all occupations combined as the standard.

For this purpose, occupations were assigned to 'job groups' in a classification similar to that which had been used in our earlier analysis. ${ }^{2}$ However, the coding schemes that were employed by ONS and OPCS had changed over time, and a few occupational categories that were distinguished from each other in one period were merged in another. To achieve compatibility across all periods, analyses for these occupations were based on the merged grouping, and for the period(s) in which the finer classification had been used, observed and expected numbers of deaths were derived separately for the subcategories and then summed to give combined values for the merged job group. Online supplementary table S1 sets out the definitions of the job groups analysed, according to the coding schemes that were applied in each period.

Similarly, cause of death categories were mostly as had been analysed previously, ${ }^{2}$ but with a few adjustments because of changes between the 9th and 10th revisions of the International Classification of Diseases (ICD-9 and ICD-10; see online supplementary table S2). Again, where for consistency it was necessary to merge cause of death categories that had not been distinguished in all time periods, observed and expected numbers of deaths were derived separately for each subcategory and then aggregated to give values for the merged grouping. One important category in ICD-10, mesothelioma unspecified, had been included in ICD-9 with all unspecified neoplasms (which were much more numerous), and therefore could not be considered in our analysis of trends.
For each cause of death that was considered an established occupational hazard, we listed those job groups in which excess mortality might plausibly be expected-for example, cancer of the pleura in carpenters and joiners (as a consequence of exposure to asbestos), railway accidents in rail construction and maintenance workers. We started with the hazards and the job groups that had been classed as at risk in our previous analysis, ${ }^{2}$ and reviewed the observed and expected numbers of deaths for those combinations of cause of death and job group during each of the three periods, 1979-1990, 1991-2000 and 2001-2010, and overall. For injury and poisoning (fatality from which is likely to be acute) and pneumonia in occupations exposed to metal fume (for which the excess risk resolves following cessation of exposure), we considered only deaths at normal working ages (20-64 years). For other hazards, we included deaths at 20-74 years. A few of the combinations of hazard and job group were excluded from further analysis because changes in classification meant that they could not be examined meaningfully, or there was no excess mortality in any of the three periods of study (see online supplementary table S3).

For each hazard and time period, we summed the observed and expected numbers of deaths across the job groups designated as being at risk, and divided the difference between the total observed and expected numbers by the length of the observation period to derive an estimate of annual excess mortality in the relevant period. To avoid bias, we applied this approach even where, in a particular job group and time period, the number of deaths observed was fewer than the number expected (ie, the excess was negative). For diseases that could occur only as a consequence of occupational exposures (eg, pneumoconiosis, farmers' lung disease), we counted also the deaths in occupations that were not designated as being at risk, and included them in our estimate of excess mortality. Where a major excess of deaths was observed for a hazard, we noted the main job groups that contributed, and where there was a substantial change in excess mortality over the duration of the study, we checked to which job groups it applied, and whether it was driven more by changes in their PMRs, in the numbers of men at risk (indicated by the number of deaths from all causes in the job groups concerned), or in mortality from that cause across all occupations.

As in our previous analysis, ${ }^{2}$ we did not attempt to evaluate trends in excess mortality from lung cancer that might be attributable to work. This was because of the major potential for confounding by smoking, the prevalence of which was expected to vary importantly between job groups and over time. Nor did we examine mortality from coronary heart disease since although it has been linked with both shift work ${ }^{3}$ and occupational stress, ${ }^{4}$ there were no job groups in which an excess of deaths could confidently be ascribed to such exposures.

\section{RESULTS}

The analysis was based on a total of 3688916 deaths, of which 1564981 occurred during 1979-1990, 1199234 in 19912000 and 924701 in 2001-2010. Table 1 sets out the numbers of deaths in each time period, across all job groups combined, from the causes of death that were examined as occupational hazards. There were marked declines in mortality from some causes including tuberculosis, cancer of the scrotum, asthma, farmers' lung disease, most types of pneumoconiosis, byssinosis and many categories of injury. On the other hand, increases were observed in deaths from viral hepatitis, cancer of the liver, other alcohol-related diseases, other and unspecified allergic pneumonitis and asbestosis. 
Table 1 Causes of death analysed and numbers of deaths by time period in all job groups combined, men aged 20-74 years, England and Wales, 1979-2010

\begin{tabular}{|c|c|c|c|c|}
\hline \multirow[b]{2}{*}{ Cause of death } & \multicolumn{3}{|c|}{$\begin{array}{l}\text { Number of deaths in all job groups combined at ages } \\
20-74 \text { years* }\end{array}$} & \multirow{2}{*}{$\begin{array}{l}\text { Per cent change in annual } \\
\text { number of deaths } \\
1979-1990 \text { to } 2000-2010\end{array}$} \\
\hline & $\begin{array}{l}1979-1980 \\
1982-1990\end{array}$ & $1991-2000$ & 2000-2010 & \\
\hline \multicolumn{5}{|l|}{ Infectious diseases } \\
\hline Tuberculosis & 3019 & 1433 & 945 & -66 \\
\hline Viral hepatitis & 544 & 592 & 998 & 102 \\
\hline \multicolumn{5}{|l|}{ Cancers } \\
\hline Cancer of the oral cavity & 3687 & 3283 & 3533 & 5 \\
\hline Cancer of the pharynx (specified) & 2830 & 2566 & 3064 & 19 \\
\hline Cancer of the liver & 5339 & 6472 & 8678 & 79 \\
\hline Cancer of the peritoneum & 362 & 365 & 363 & 10 \\
\hline Cancer of the nose and nasal sinuses and middle ear & 839 & 518 & 400 & -48 \\
\hline Cancer of the larynx & 4832 & 3962 & 3213 & -27 \\
\hline Cancer of the pleura & 2848 & 2894 & 2314 & -11 \\
\hline Mesothelioma at other sites and unspecified combined & & & 6114 & \\
\hline Other cancer of skin (excluding melanoma) & 1219 & 910 & 722 & -35 \\
\hline Cancer of the scrotum & 85 & 29 & 16 & -79 \\
\hline Urothelial cancer & 18403 & 14184 & 10691 & -36 \\
\hline \multicolumn{5}{|l|}{ Other alcohol-related diseases } \\
\hline Other alcohol-related diseases (excluding alcohol poisoning) & 8216 & 14530 & 26701 & 257 \\
\hline \multicolumn{5}{|l|}{ Respiratory diseases } \\
\hline Combined pneumonia (excluding bronchopnuemonia) & 3672 & 4410 & 4191 & 26 \\
\hline Chronic bronchitis and emphysema & 85096 & 54941 & 38955 & -50 \\
\hline Asthma & 5586 & 3441 & 1630 & -68 \\
\hline Farmer's lung disease & 66 & 34 & 17 & -72 \\
\hline Other and unspecified allergic pneumonitis & 24 & 36 & 68 & 212 \\
\hline Coal worker's pneumoconiosis & 942 & 498 & 210 & -75 \\
\hline Asbestosis & 281 & 331 & 407 & 59 \\
\hline Silicosis & 163 & 50 & 39 & -74 \\
\hline Other pneumoconiosis combined & 244 & 98 & 49 & -78 \\
\hline Byssinosis & 39 & 6 & 1 & -97 \\
\hline \multicolumn{5}{|l|}{ Digestive diseases } \\
\hline Cirrhosis (not specified as biliary) & 5327 & 5533 & 6469 & 34 \\
\hline Pancreatitis & 2785 & 2718 & 2758 & 9 \\
\hline \multicolumn{5}{|l|}{ Injury and poisoning } \\
\hline Railway accidents combined & 562 & 239 & 142 & -72 \\
\hline Motor vehicle traffic accidents combined & 20428 & 11952 & 10154 & -45 \\
\hline Off-road motor vehicle traffic accidents combined & 476 & 261 & 132 & -69 \\
\hline Animal transport accidents rider/passenger & 53 & 26 & 20 & -58 \\
\hline Water transport accidents & 499 & 173 & 126 & -72 \\
\hline Air transport accident & 427 & 216 & 92 & -76 \\
\hline Pesticide poisoning & 11 & 5 & 5 & -50 \\
\hline Poisoning by other gases and vapours combined & 617 & 263 & 177 & -68 \\
\hline Fall from ladder or scaffolding & 606 & 294 & 208 & -62 \\
\hline Fall from building & 900 & 416 & 358 & -56 \\
\hline Fall into hole & 96 & 35 & 115 & 32 \\
\hline Other fall & 428 & 291 & 171 & -56 \\
\hline Slipping and tripping & 121 & 91 & 74 & -33 \\
\hline Fall unspecified & 1040 & 877 & 1230 & 30 \\
\hline Injured by fire & 1202 & 871 & 577 & -47 \\
\hline Heat injury & 14 & 10 & 5 & -61 \\
\hline Injury by animals and plants combined & 41 & 42 & 46 & 23 \\
\hline Injury by lightning & 20 & 14 & 5 & -73 \\
\hline Injury by falling, thrown or projected object & 647 & 263 & 160 & -73 \\
\hline Injury by being caught between objects & 54 & 31 & 24 & -51 \\
\hline Injury by machinery & 907 & 341 & 89 & -89 \\
\hline Injury by cutting and piercing instruments or objects & 88 & 72 & 29 & -64 \\
\hline Injury by explosion of pressure vessel & 30 & 16 & 5 & -82 \\
\hline
\end{tabular}


Table 1 Continued

\begin{tabular}{|c|c|c|c|c|}
\hline \multirow[b]{2}{*}{ Cause of death } & \multicolumn{3}{|c|}{$\begin{array}{l}\text { Number of deaths in all job groups combined at ages } \\
20-74 \text { years* }\end{array}$} & \multirow{2}{*}{$\begin{array}{l}\text { Per cent change in annual } \\
\text { number of deaths } \\
1979-1990 \text { to } 2000-2010\end{array}$} \\
\hline & $\begin{array}{l}1979-1980 \\
1982-1990\end{array}$ & $1991-2000$ & 2000-2010 & \\
\hline Injury by firearms & 95 & 44 & 17 & -80 \\
\hline Injury by explosive material & 148 & 52 & 12 & -91 \\
\hline Injury by hot substances & 54 & 28 & 13 & -74 \\
\hline Injury by electric current & 452 & 255 & 144 & -65 \\
\hline Homicide & 1234 & 1038 & 1098 & -2 \\
\hline War & 28 & 3 & 1 & -96 \\
\hline
\end{tabular}

Table 2 lists the job groups that were considered a priori to be at risk of one or more of the identified occupational hazards, and gives the total number of deaths in each job group by time period. In most job groups, the number of deaths declined over the period of study, the fall being most marked in traditional manufacturing occupations, and in rail travel assistants and dockers. There was, however, a notable increase in deaths in professional athletes and sports officials. A reduction in deaths among electrical, energy, boiler operatives and attendants was largely offset by an increase for other transport, plant and machine operatives.

Table 3 summarises the trends in excess mortality from diseases caused by occupational exposure to dusts and fumes (here and in tables 4 and 5, some of the results for 1979-1990 and 1991-2000 differ slightly from those in our earlier paper ${ }^{2}$ because of the aggregation of job groups that was necessary to achieve compatibility across the three time periods, and because in this study, deficits of observed vs expected deaths were counted as negative numbers rather than 0 ). The overall excess of deaths declined from an annual average of 414.8 during 1979-1990 to 272.6 in 1991-2000. The new category of deaths from mesothelioma at unspecified sites, which was distinguished only during 2001-2010, accounted for 135.9 excess deaths per year. In the same period, total excess mortality from the other causes of death showed a further decrease to 312.8$135.9=176.9$ deaths per year.

The main contributors to the progressive decline in excess mortality were chronic bronchitis and emphysema, and coal workers' pneumoconiosis, for which the annual excesses of deaths fell from 170.7 to 36.0 and 85.6 to 21.0 , respectively. These reductions were driven largely by the fall in the population of coal miners, as evidenced by a decrease in all-cause mortality from 47249 deaths during 1979-1990 to 14208 in 2001-2010 (table 2). However, as illustrated in online supplementary table S4, which shows a detailed breakdown of excess mortality for individual job groups, there was in addition, a small decrease in the PMR for chronic bronchitis and emphysema in coal miners from 144 to 128 . For silicosis, farmers' lung disease and pneumonia, the decrease in excess mortality was also beyond that which could be explained by a fall in the numbers at risk. The lowering in excess occupational mortality from tuberculosis and asthma coincided with falls in the annual numbers of deaths from those diseases across all occupations by $66 \%$ and $68 \%$, respectively (table 1 ), but there was also a reduction in the PMRs of the job group at highest risk of tuberculosis —mine (excluding coal) and quarry workers-from 431 to 172.

In contrast to the improving picture for most diseases caused by dusts and fumes, excess mortality from sinonasal cancer and from diseases caused by asbestos remained fairly constant, or in the case of asbestosis, increased. The main job groups contributing to the rise in mortality from asbestosis were carpenters and joiners (18.9 excess deaths in 2001-2010 vs 3.8 in 19791991), plumbers (23.1 vs 9.8) and platers (13.4 vs 1.9; see online supplementary table S4). Mesothelioma at unspecified sites was only distinguished as a separate diagnostic category in ICD-10, but PMRs for the asbestos-exposed occupations during 2001-2010 correlated closely with those for cancer of the pleura (correlation coefficient 0.81 , see online supplementary figure S1).

Over the entire study period, the calculated excess mortality among occupations designated as being at risk accounted for $88 \%$ of the 1650 deaths from coal workers' pneumoconiosis, $58 \%$ of 1019 deaths from asbestosis, $65 \%$ of 252 deaths from silicosis, $85 \%$ of 117 deaths from farmers' lung disease, and $52 \%$ of 9146 deaths from cancers of the peritoneum and pleura combined (see online supplementary table S4).

Trends in excess mortality from other diseases caused by work are summarised in table 4. Reductions in excess deaths were observed for non-melanoma skin cancer in occupations particularly exposed to sunlight, and for cancer of the scrotum in those with exposure to mineral oils, while for viral hepatitis in doctors and urothelial cancer in chemical workers, excess mortality was small with no clear trends across the study period (see online supplementary table S5). Publicans and bar staff (in the UK, publicans own or manage 'public houses' that are licensed to sell alcoholic drinks for consumption on the premises) experienced consistently elevated mortality from diseases caused by alcohol, but their annual excess of deaths from cirrhosis and pancreatitis declined over time, whereas that from cancers of the pharynx and liver increased (see table 4 and online supplementary table S5). There was a parallel rise in deaths from cancer of the liver in all occupations combined, but total mortality from cirrhosis and pancreatitis showed no overall decline across the study period (table 1 ).

Table 5 and online supplementary table S6 summarise patterns of mortality from injury and poisoning. The overall annual excess of deaths in occupations at risk fell from 237.0 during 1979-1990 to 137.4 in 1991-2000, and 87.5 in 2001-2010. This substantial decline was driven by reductions in most of the major categories of injury, including a notable fall in the excess of deaths from railway accidents among railway workers from 11.7 per year in $1979-1990$ to 0.4 deaths per year during 2001-2010. One exception to the general downward trend was excess mortality from injury by animals and plants in farmers, which remained fairly constant at 1.0-1.4 deaths per year (see online supplementary table S6). 
Table 2 Job groups analysed and numbers of deaths from all causes by time period, men aged 20-74 years, England and Wales, 1979-2010

\begin{tabular}{|c|c|c|c|c|}
\hline \multirow[b]{2}{*}{ Job group } & \multicolumn{3}{|c|}{$\begin{array}{l}\text { Number of deaths from all causes combined at } \\
\text { ages } 20-74 \text { years }\end{array}$} & \multirow{2}{*}{$\begin{array}{l}\text { Per cent change in annua } \\
\text { number of deaths } \\
1979-90 \text { to } 2000-10\end{array}$} \\
\hline & $\begin{array}{l}1979-1980 \\
1982-90\end{array}$ & $1991-2000$ & $2000-2010$ & \\
\hline Marketing and sales managers combined & 14454 & 14132 & 19105 & 45 \\
\hline Vocational trainers, social scientists, etc & 3828 & 3855 & 3415 & -2 \\
\hline Doctors & 4086 & 3263 & 2807 & -24 \\
\hline Other health professions combined & 2360 & 2431 & 1962 & -9 \\
\hline Professional athletes, sports officials & 482 & 624 & 1068 & 144 \\
\hline Chemical engineers and scientists & 2554 & 2539 & 2018 & -13 \\
\hline Other professional engineers & 16766 & 17230 & 14787 & -3 \\
\hline Draughtspersons & 6057 & 5076 & 3365 & -39 \\
\hline Laboratory technicians & 5795 & 3325 & 2331 & -56 \\
\hline Aircraft flight deck officers & 619 & 814 & 574 & 2 \\
\hline Seafarers & 8600 & 6963 & 4780 & -39 \\
\hline Other technicians & 4593 & 6308 & 6276 & 50 \\
\hline Production and maintenance managers & 27591 & 21689 & 14224 & -43 \\
\hline Managers in construction & 7036 & 5578 & 5465 & -15 \\
\hline Managers in transport, mining and energy industries & 16247 & 13517 & 9562 & -35 \\
\hline Butchers & 9739 & 6364 & 4087 & -54 \\
\hline Publicans and bar staff & 17415 & 12446 & 10346 & -35 \\
\hline Farming and fishing combined & 58113 & 40782 & 30071 & -43 \\
\hline Armed forces & 10037 & 8204 & 8266 & -9 \\
\hline Police & 7273 & 7426 & 6812 & 3 \\
\hline Fire service personnel & 2805 & 2643 & 1920 & -25 \\
\hline Sales representatives & 24234 & 15869 & 10839 & -51 \\
\hline Other service personnel combined & 40181 & 34143 & 23204 & -36 \\
\hline Rail travel assistants combined & 9749 & 6331 & 1032 & -88 \\
\hline Forestry workers & 1459 & 1090 & 675 & -49 \\
\hline Leather and related trades combined & 6108 & 3189 & 1078 & -81 \\
\hline Weavers and knitters combined & 3386 & 1782 & 860 & -72 \\
\hline Other textile processing operatives combined & 10185 & 2339 & 1419 & -85 \\
\hline Chemical workers combined & 18146 & 9821 & 5117 & -69 \\
\hline Bakers & 5371 & 4020 & 1950 & -60 \\
\hline Other food drink and tobacco process operatives nec combined & 10391 & 7330 & 5886 & -38 \\
\hline Paper and wood machine operatives combined & 8882 & 4946 & 3104 & -62 \\
\hline Glass and ceramic workers combined & 7846 & 4422 & 2628 & -63 \\
\hline Coal miners combined & 47249 & 27896 & 14208 & -67 \\
\hline Upholsterers & 2620 & 1574 & 1265 & -47 \\
\hline Carpenters and joiners & 25914 & 22049 & 20817 & -12 \\
\hline Cabinet makers combined & 3972 & 2822 & 2276 & -37 \\
\hline Smiths and forge workers & 2633 & 1570 & 836 & -65 \\
\hline Moulders, core makers, die casters & 4607 & 2198 & 909 & -78 \\
\hline Electroplaters combined & 1273 & 849 & 509 & -56 \\
\hline Other metal manufacturers combined & 12224 & 7613 & 3825 & -66 \\
\hline Metal machining setters and setter-operators combined & 11349 & 10482 & 4582 & -56 \\
\hline Metal working machine operatives combined & 54442 & 34154 & 24181 & -51 \\
\hline Production fitters & 49781 & 38535 & 23220 & -49 \\
\hline Motor mechanics, auto engineers combined & 14788 & 13162 & 11536 & -14 \\
\hline Electricians, electrical maintenance fitters combined & 20719 & 18381 & 21253 & 13 \\
\hline Cable jointers, lines repairers & 1728 & 1362 & 824 & -48 \\
\hline Radio, TV and video engineers & 2025 & 1698 & 1220 & -34 \\
\hline Electrical engineers (not professional) combined & 7803 & 6753 & 4836 & -32 \\
\hline Plumbers, heating and ventilating engineers and related trades & 16019 & 14797 & 14046 & -4 \\
\hline Sheet metal workers & 7529 & 4806 & 2919 & -57 \\
\hline Metal plate workers, shipwrights, riveters & 5560 & 4120 & 2151 & -57 \\
\hline Steel erectors & 3517 & 3675 & 1837 & -43 \\
\hline Scaffolders, riggers combined & 3321 & 3484 & 2898 & -4 \\
\hline Welding trades & 11783 & 10414 & 8140 & -24 \\
\hline Coach and vehicle body builders and repairers combined & 2122 & 2324 & 2006 & 4 \\
\hline
\end{tabular}


Table 2 Continued

\begin{tabular}{|c|c|c|c|c|}
\hline \multirow[b]{2}{*}{ Job group } & \multicolumn{3}{|c|}{$\begin{array}{l}\text { Number of deaths from all causes combined at } \\
\text { ages } 20-74 \text { years }\end{array}$} & \multirow{2}{*}{$\begin{array}{l}\text { Per cent change in annual } \\
\text { number of deaths } \\
1979-90 \text { to } 2000-10\end{array}$} \\
\hline & $\begin{array}{l}1979-1980 \\
1982-90\end{array}$ & $1991-2000$ & $2000-2010$ & \\
\hline Painters and decorators & 28103 & 21241 & 18661 & -27 \\
\hline Assemblers/lineworkers (electrical/electronic goods) & 1031 & 1903 & 1363 & 45 \\
\hline Packers, sorters and testers combined & 7947 & 15376 & 8563 & 19 \\
\hline Bricklayers, masons combined & 17359 & 11288 & 8412 & -47 \\
\hline Roofers and glaziers & 3267 & 3908 & 5610 & 89 \\
\hline Rail construction and maintenance workers & 3020 & 1590 & 761 & -72 \\
\hline Road construction workers and paviors & 4947 & 3329 & 2979 & -34 \\
\hline Other construction workers combined & 48602 & 45154 & 59230 & 34 \\
\hline Mine (excluding coal) and quarry workers & 2580 & 1658 & 1279 & -45 \\
\hline Rail transport operatives combined & 2994 & 1707 & 3415 & 25 \\
\hline Railway engine drivers & 4179 & 3836 & 1682 & -56 \\
\hline Lorry drivers & 58475 & 54545 & 48106 & -10 \\
\hline Mechanical plant drivers and operatives (earth moving and civil engineering) & 2805 & 3736 & 3673 & 44 \\
\hline Crane drivers & 8153 & 4887 & 2713 & -63 \\
\hline Fork lift and mechanical truck drivers & 6330 & 6967 & 6771 & 18 \\
\hline Storekeepers and warehousemen/women & 46739 & 28467 & 19928 & -53 \\
\hline Dockers goods porters and slingers combined & 14154 & 9443 & 2829 & -78 \\
\hline Electrical, energy, boiler operatives and attendants combined & 9428 & 4393 & 1818 & -79 \\
\hline Other transport, plant and machine operatives combined & 3146 & 12523 & 9418 & 229 \\
\hline
\end{tabular}

Table 3 Excess mortality from diseases caused by occupational exposure to dusts and fumes, men aged $20-74$ years, ${ }^{*}$ England and Wales, 1979-2010

\begin{tabular}{|c|c|c|c|c|c|c|c|c|c|c|}
\hline \multirow[b]{2}{*}{ Cause of death } & \multirow[b]{2}{*}{ Exposure } & \multicolumn{3}{|c|}{ 1979-1980, 1982-1990 } & \multicolumn{3}{|l|}{$1991-2000$} & \multicolumn{3}{|l|}{$2001-2010$} \\
\hline & & $\begin{array}{l}\text { Deaths } \\
\text { observedt }\end{array}$ & $\begin{array}{l}\text { Deaths } \\
\text { expectedt }\end{array}$ & $\begin{array}{l}\text { Annual } \\
\text { excesst }\end{array}$ & $\begin{array}{l}\text { Deaths } \\
\text { observedt }\end{array}$ & $\begin{array}{l}\text { Deaths } \\
\text { expectedt }\end{array}$ & $\begin{array}{l}\text { Annual } \\
\text { excesst }\end{array}$ & $\begin{array}{l}\text { Deaths } \\
\text { observedt }\end{array}$ & $\begin{array}{l}\text { Deaths } \\
\text { expectedt }\end{array}$ & $\begin{array}{l}\text { Annual } \\
\text { excess } t\end{array}$ \\
\hline $\begin{array}{l}\text { Coal workers' } \\
\text { pneumoconiosis }\end{array}$ & Coal mine dust & 942 & & 85.6 & 498 & & 49.8 & 210 & & 21.0 \\
\hline Asbestosis & Asbestos & 281 & & 25.5 & 331 & & 33.1 & 407 & & 40.7 \\
\hline Cancer of the peritoneum & Asbestos & 178 & 94.7 & 7.6 & 168 & 93.6 & 7.4 & 173 & 100.3 & 7.3 \\
\hline Cancer of the pleura & Asbestos & 1491 & 792.5 & 63.5 & 1495 & 836.5 & 65.8 & 1239 & 681.4 & 55.8 \\
\hline $\begin{array}{l}\text { Mesothelioma at unspecified } \\
\text { and other sites combined }\end{array}$ & Asbestos & & & & & & & 3149 & 1790.3 & 135.9 \\
\hline Silicosis & Silica dust & 163 & & 14.8 & 50 & & 5.0 & 39 & & 3.9 \\
\hline Tuberculosis & Silica dust & 88 & 60.8 & 2.5 & 42 & 24.5 & 1.7 & 23 & 15.0 & 0.8 \\
\hline $\begin{array}{l}\text { Other pneumoconiosis } \\
\text { combined }\end{array}$ & Various & 244 & & 22.2 & 98 & & 9.8 & 49 & & 4.9 \\
\hline Byssinosis & Textile dust & 39 & & 3.5 & 6 & & 0.6 & 1 & & 0.1 \\
\hline Farmers' lung disease & $\begin{array}{l}\text { Spores in mouldy } \\
\text { hay }\end{array}$ & 66 & & 6.0 & 34 & & 3.4 & 17 & & 1.7 \\
\hline $\begin{array}{l}\text { Other and unspecified allergic } \\
\text { pneumonitis }\end{array}$ & Various & 7 & 0.9 & 0.6 & 3 & 1.1 & 0.2 & 8 & 1.8 & 0.6 \\
\hline $\begin{array}{l}\text { Cancer of the nose and nasal } \\
\text { sinuses and middle ear }\end{array}$ & $\begin{array}{l}\text { Leather dust, } \\
\text { wood dust }\end{array}$ & 50 & 25.4 & 2.2 & 35 & 15.4 & 2.0 & 30 & 11.7 & 1.8 \\
\hline $\begin{array}{l}\text { Combined pneumonia } \\
\text { (excluding } \\
\text { bronchopneumonia) }\end{array}$ & Metal fume & 164 & 87.0 & 7.0 & 122 & 80.2 & 4.2 & 89 & 75.6 & 1.3 \\
\hline $\begin{array}{l}\text { Chronic bronchitis and } \\
\text { emphysema }\end{array}$ & $\begin{array}{l}\text { Coal mine dust, } \\
\text { silica dust, metal } \\
\text { fume }\end{array}$ & 7391 & 5513.8 & 170.7 & 3889 & 3041.7 & 84.7 & 2063 & 1702.6 & 36.0 \\
\hline Asthma & Various & 156 & 122.1 & 3.1 & 142 & 93.7 & 4.8 & 44 & 34.3 & 1.0 \\
\hline Total & & 11260 & 6697.2 & 414.8 & 6913 & 4186.7 & 272.6 & 7541 & 4413.0 & 312.8 \\
\hline
\end{tabular}

*Deaths from pneumonia in relation to metal fume are at ages 20-64 years. tFor coal workers' pneumoconiosis, asbestosis, silicosis, other pneumoconiosis combined, byssinosis and farmers' lung disease, the number of deaths observed is for all occupations
combined, and was used to calculate the annual excess. For all other hazards, the numbers of deaths observed and expected are for job groups designated as being at risk (see text on methods and online Supplementary table S4), and the excess rate was based on the difference between observed and expected. 
Table 4 Excess mortality from diseases with other occupational causes: men aged 20-74 years, England and Wales 1979-2010

\begin{tabular}{|c|c|c|c|c|c|c|c|c|c|c|}
\hline \multirow[b]{2}{*}{ Cause of death } & \multirow[b]{2}{*}{ Exposure } & \multicolumn{3}{|c|}{ 1979-1980, 1982-1990 } & \multicolumn{3}{|l|}{ 1991-2000 } & \multicolumn{3}{|l|}{ 2001-2010 } \\
\hline & & $\begin{array}{l}\text { Deaths } \\
\text { observed* }\end{array}$ & $\begin{array}{l}\text { Deaths } \\
\text { expected* }\end{array}$ & $\begin{array}{l}\text { Annual } \\
\text { excess* }\end{array}$ & $\begin{array}{l}\text { Deaths } \\
\text { observed* }\end{array}$ & $\begin{array}{l}\text { Deaths } \\
\text { expected* }\end{array}$ & $\begin{array}{l}\text { Annual } \\
\text { excess* }\end{array}$ & $\begin{array}{l}\text { Deaths } \\
\text { observed* }\end{array}$ & $\begin{array}{l}\text { Deaths } \\
\text { expected* }\end{array}$ & $\begin{array}{l}\text { Annual } \\
\text { excess* }\end{array}$ \\
\hline Viral hepatitis & $\begin{array}{l}\text { Hepatitis } \\
\text { infection }\end{array}$ & 14 & 3.2 & 1.0 & 8 & 2.7 & 0.5 & 10 & 3.0 & 0.7 \\
\hline Cancer of the oral cavity & Alcohol & 117 & 42.6 & 6.8 & 110 & 35.3 & 7.5 & 109 & 43.1 & 6.6 \\
\hline Cancer of the pharynx & Alcohol & 71 & 30.8 & 3.7 & 67 & 28.2 & 3.9 & 83 & 38.7 & 4.4 \\
\hline Cancer of the liver & Alcohol & 112 & 69.1 & 3.9 & 125 & 81.8 & 4.3 & 165 & 107.6 & 5.7 \\
\hline Cancer of the larynx & Alcohol & 119 & 45.4 & 6.7 & 100 & 36.1 & 6.4 & 75 & 34.6 & 4.0 \\
\hline Cirrhosis (not specified as biliary) & Alcohol & 243 & 80.9 & 14.7 & 170 & 72.0 & 9.8 & 145 & 79.9 & 6.5 \\
\hline Pancreatitis & Alcohol & 45 & 33.6 & 1.0 & 32 & 31.4 & 0.1 & 31 & 30.5 & 0.0 \\
\hline $\begin{array}{l}\text { Other alcohol-related diseases } \\
\text { (excluding alcohol poisoning) }\end{array}$ & Alcohol & 458 & 125.4 & 30.2 & 449 & 185.9 & 26.3 & 662 & 319.0 & 34.3 \\
\hline Non-melanoma skin cancer & Sunlight & 99 & 83.8 & 1.4 & 70 & 60.6 & 0.9 & 71 & 63.8 & 0.7 \\
\hline Urothelial cancer & $\begin{array}{l}\text { Aromatic } \\
\text { amines }\end{array}$ & 224 & 208.8 & 1.4 & 145 & 116.8 & 2.8 & 85 & 68.7 & 1.6 \\
\hline Cancer of the scrotum & Mineral oils & 24 & 7.7 & 1.5 & 7 & 2.1 & 0.5 & 2 & 0.9 & 0.1 \\
\hline Total & & 1526 & 731.1 & 72.3 & 1283 & 653.0 & 63.0 & 1438 & 789.8 & 64.8 \\
\hline
\end{tabular}

${ }^{*}$ The numbers of deaths observed and expected are for job groups designated as being at risk (listed in online supplementary table S5), and the excess rate was based on the difference between observed and expected.

Table 5 Excess mortality from occupational injuries and poisoning: men aged 20-64 years, England and Wales 1979-2010

\begin{tabular}{|c|c|c|c|c|c|c|c|c|c|}
\hline \multirow[b]{2}{*}{ Cause of death } & \multicolumn{3}{|c|}{ 1979-1980, 1982-1990 } & \multicolumn{3}{|l|}{$1991-2000$} & \multicolumn{3}{|l|}{ 2001-2010 } \\
\hline & $\begin{array}{l}\text { Deaths } \\
\text { observed* }\end{array}$ & $\begin{array}{l}\text { Deaths } \\
\text { expected* }\end{array}$ & $\begin{array}{l}\text { Annual } \\
\text { excess* }\end{array}$ & $\begin{array}{l}\text { Deaths } \\
\text { observed* }\end{array}$ & $\begin{array}{l}\text { Deaths } \\
\text { expected* }\end{array}$ & $\begin{array}{l}\text { Annual } \\
\text { excess* }\end{array}$ & $\begin{array}{l}\text { Deaths } \\
\text { observed* }^{*}\end{array}$ & $\begin{array}{l}\text { Deaths } \\
\text { expected* }\end{array}$ & $\begin{array}{l}\text { Annual } \\
\text { excess* }\end{array}$ \\
\hline Railway accidents combined & 134 & 4.8 & 11.7 & 25 & 1.5 & 2.4 & 5 & 0.7 & 0.4 \\
\hline Motor vehicle traffic accidents combined & 2358 & 1561.8 & 72.4 & 1655 & 1034.1 & 62.1 & 1547 & 991.1 & 55.6 \\
\hline Off-road motor vehicle traffic accidents combined & 190 & 76.6 & 10.3 & 118 & 43.6 & 7.4 & 75 & 21.4 & 5.4 \\
\hline Animal transport accidents & 14 & 2.4 & 1.1 & 14 & 1.1 & 1.3 & 6 & 0.5 & 0.5 \\
\hline Water transport accidents & 168 & 31.0 & 12.5 & 52 & 9.3 & 4.3 & 27 & 4.5 & 2.3 \\
\hline Air transport accidents & 116 & 6.9 & 9.9 & 55 & 2.3 & 5.3 & 17 & 1.1 & 1.6 \\
\hline Pesticide poisoning & 4 & 0.2 & 0.3 & 4 & 0.3 & 0.4 & 1 & 0.1 & 0.1 \\
\hline Poisoning by other gases and vapours combined & 53 & 43.8 & 0.8 & 24 & 18.4 & 0.6 & 21 & 14.2 & 0.7 \\
\hline Fall from ladder or scaffolding & 321 & 96.7 & 20.4 & 138 & 55.0 & 8.3 & 90 & 46.5 & 4.3 \\
\hline Fall from building & 416 & 143.1 & 24.8 & 164 & 71.0 & 9.3 & 140 & 90.8 & 4.9 \\
\hline Fall into hole & 22 & 6.1 & 1.4 & 6 & 2.4 & 0.4 & 7 & 8.2 & -0.1 \\
\hline Other fall & 91 & 45.3 & 4.2 & 55 & 26.9 & 2.8 & 22 & 16.6 & 0.5 \\
\hline Slipping and tripping & 12 & 4.7 & 0.7 & 8 & 3.8 & 0.4 & 7 & 2.9 & 0.4 \\
\hline Fall unspecified & 94 & 78.6 & 1.4 & 105 & 75.3 & 3.0 & 162 & 138.7 & 2.3 \\
\hline Injured by fire & 8 & 1.8 & 0.6 & 5 & 1.8 & 0.3 & 1 & 1.3 & 0.0 \\
\hline Heat injury & 4 & 0.2 & 0.3 & 2 & 0.1 & 0.2 & 0 & 0.1 & 0.0 \\
\hline Injury by animals and plants combined & 17 & 2.2 & 1.3 & 16 & 1.6 & 1.4 & 11 & 1.3 & 1.0 \\
\hline Injury by lightning & 3 & 0.9 & 0.2 & 3 & 0.6 & 0.2 & 0 & 0.0 & 0.0 \\
\hline Injury by falling, thrown or projected object & 286 & 121.5 & 15.0 & 117 & 49.9 & 6.7 & 63 & 35.1 & 2.8 \\
\hline Injury by being caught between objects & 15 & 7.0 & 0.7 & 11 & 3.3 & 0.8 & 5 & 2.1 & 0.3 \\
\hline Injury by machinery & 521 & 201.8 & 29.0 & 187 & 73.3 & 11.4 & 45 & 21.4 & 2.4 \\
\hline $\begin{array}{l}\text { Injury by cutting and piercing instruments or } \\
\text { objects }\end{array}$ & 22 & 8.1 & 1.3 & 15 & 7.3 & 0.8 & 9 & 5.3 & 0.4 \\
\hline Injury by explosion of pressure vessel & 6 & 1.7 & 0.4 & 6 & 1.2 & 0.5 & 1 & 0.0 & 0.1 \\
\hline Injury by firearms & 32 & 5.4 & 2.4 & 14 & 2.3 & 1.2 & 3 & 0.8 & 0.2 \\
\hline Injury by explosive material & 55 & 20.7 & 3.1 & 14 & 7.0 & 0.7 & 3 & 1.8 & 0.1 \\
\hline Injury by hot substances & 18 & 3.7 & 1.3 & 8 & 1.6 & 0.6 & 1 & 0.8 & 0.0 \\
\hline Injury by electric current & 145 & 61.6 & 7.6 & 80 & 34.6 & 4.5 & 41 & 28.2 & 1.3 \\
\hline Homicide & 16 & 5.8 & 0.9 & 7 & 6.2 & 0.1 & 4 & 4.6 & -0.1 \\
\hline War & 10 & 0.3 & 0.9 & 2 & 0.1 & 0.2 & 1 & 0.0 & 0.1 \\
\hline Total & 5151 & 2544.5 & 237.0 & 2910 & 1535.9 & 137.4 & 2315 & 1440.0 & 87.5 \\
\hline
\end{tabular}

\footnotetext{
*The numbers of deaths observed and expected are for job groups designated as being at risk (listed in online supplementary table S6), and the excess rate was based on the difference
} between observed and expected. 


\section{DISCUSSION}

Our findings indicate that over recent decades, there has been a large and continuing fall in mortality from most of the occupational hazards considered. In many cases, this appears to have come about through improved safety, but it also reflects reductions in the numbers of men employed in more hazardous jobs such as coal mining, and falling mortality from some diseases across the whole population. Notable exceptions to the general improvement are diseases caused by asbestos, especially in some construction trades, sinonasal cancer in woodworkers, and injuries by animals and plants in farmworkers, for which there was still no clear decline in excess mortality.

As in our previous report, ${ }^{2}$ we limited our analysis of trends to men. This was because in the early part of the study period, most women who died at age 20-74 years had spent only limited time in paid work, and during 1979-1990, only 30\% had occupations recorded on their death certificates. ${ }^{5}$ Furthermore, with a few notable exceptions (eg, production of asbestos textiles ${ }^{6}$ ), the jobs in which they have been employed were not those in which excess mortality could confidently be attributed to occupational hazards. We plan to report on occupational mortality among women during 2001-2010 in a separate paper.

Our analysis had the advantage of covering all deaths nationally among men of working age over a prolonged period, which allowed trends to be evaluated with maximal statistical confidence. Against this, however, must be set a number of methodological limitations, which relate principally to the accuracy with which causes of death and occupational exposures could be determined, and the potential for confounding by nonoccupational factors.

Cause of death was ascertained from death certificates, a source that is known not always to be accurate. ${ }^{7}$ Fewer errors might be expected for established occupational diseases such as pneumoconiosis, and for injury and poisoning, all of which are classed as unnatural causes of death and therefore are subject to more detailed investigation. However, diagnostic errors may have had a greater impact on, for example, cancer of the liver, which can be difficult to distinguish from hepatic metastasis of malignancies arising in other tissues. In general, misclassification of causes of death is likely to have been non-differential with respect to job group, biasing PMRs towards the null.

A further problem in assessing causes of death was the lack of specificity of some ICD categories. This applied particularly to mesothelioma at unspecified sites, which in ICD-9 was classed along with other cancers of unknown origin that were much more numerous. Analysis of data from 2001 to 2010, when ICD-10 was used, indicated that PMRs from unspecified mesothelioma correlated closely with those for pleural cancer (see online supplementary figure S1), and that excess numbers of deaths were some 2.5 times higher (see online supplementary table S4).

Incomplete diagnostic specificity was also a problem for deaths caused by injury and poisoning, the detailed circumstances of which were unknown. As a consequence, attribution to work could only be made with reasonable confidence when the category of injury was likely to be a particular hazard in a job group. Other injuries resulting from work will have been missed, and this explains why the annual excess deaths are substantially lower than the incidence of fatal occupational injuries assessed from closer investigation of individual cases. During 2001-2010, the UK Health and Safety Executive (HSE) recorded in excess of 200 fatal injuries per year to workers. ${ }^{8}$ Our estimate of 87.8 was limited to men, but unlike the HSE statistics, it included deaths from road traffic accidents and in the armed forces.

Data on occupation were also derived from death certificates, and again will not have been completely accurate. ${ }^{9}$ Analysis of proportional mortality avoided the biases that can occur when different sources of occupational information are used for the numerator and denominator of death rates, but at the expense of possible bias if mortality in a job group from all causes combined was unusually low or high. In addition, as with causes of death, some occupational categories lacked desirable specificity. For example, because of changes in occupational classification, stone masons (who can have high exposures to silica) were grouped with bricklayers. The resultant 'dilution' will have led to lower PMRs, although it should not have biased estimates of excess numbers of deaths.

More important was the potential to miss long-term effects of hazardous exposures where men had changed employment and the last full-time occupation as recorded on the death certificate was not that in which the relevant exposure occurred. For example, as they approach retirement, some manual workers may move to jobs that are less physically demanding, and others may have changed their employment as some of the more hazardous industries contracted. Some indication of magnitude of this underascertainment can be gleaned from the findings for disease that are specific to occupational exposures. For example, coal mining occupations were reported for only $88 \%$ of deaths from coal workers' pneumoconiosis, and only $65 \%$ of deaths from silicosis occurred in men whose last occupation was classed as potentially exposed to silica. For mesothelioma, which can develop as a consequence of relatively short exposures to asbestos many years in the past, the underascertainment because of changes in employment may have been even greater. Over the full study period, excess mortality in the occupations designated as being at risk accounted for only $52 \%$ of all deaths from cancers of the peritoneum and pleura, whereas the true attributable fraction is likely to have been closer to $85 \%{ }^{10}$

Confounding by non-occupational factors will have been reduced by the adjustment of expected numbers of deaths for social class. However, it remains a potential problem for diseases caused by smoking, the prevalence of which can vary importantly between occupations, even within the same social class. The relative risk from smoking, and therefore the scope for confounding, is particularly high for lung cancer, and trends in occupational lung cancer, which require more complex assessment, will be considered in a separate report. Confounding may also have caused us to overestimate the burden of alcoholrelated diseases attributable to work in bars. Some of the diseases (notably cancers of the oral cavity, pharynx and larynx) are also caused by smoking, which may be more prevalent in bar workers. Furthermore, while ready access to alcohol poses an important hazard in such employment, there may also be a tendency for heavy drinkers to take on jobs in bars selectively.

Overall, the effect of the various limitations discussed will have been a net underascertainment of the burden of mortality attributable to occupation. However, we think it unlikely that many of the estimates for occupational diseases will have been out by a factor of $>3$. Bearing in mind this scope for error, the estimates for sinonasal cancer in workers exposed to wood and leather dust can be compared with those derived by Slack et $a l^{11}$ using different methodology. Applying risk estimates derived from published studies to estimates of the proportion of the national population ever exposed, they calculated population attributable fractions for mortality from sinonasal cancer in men during 2005 of 0.1533 (95\% CI 0.0594 to 0.2912 ) for wood 
dust and 0.0668 (95\% CI 0.0328 to 0.1231 ) for leather dust. If applied to the average annual number of deaths from sinonasal cancer among men aged 20-74 during 2001-2010, which was 40 (see table 1), these figures give annual excess numbers of deaths of 6.1 (95\% CI 2.4 to 11.6) for wood dust and 2.7 (95\% CI 1.3 to 4.8 ) for leather dust. In comparison, we estimated annual excesses of 1.9 deaths for all woodworkers combined, and 0 for leather workers. Moreover, across all of 1979-2010, the annual excess of deaths in leather workers was less than 0.1 . If extrapolated to this period, the lower 95\% confidence limit of Slack's estimate would correspond to a cumulative excess of $1.3 \times 31=40.3$ deaths, whereas we observed only 8 deaths in total with 5.1 expected (see online supplementary table S4). While the two estimates for wood dust might be compatible, those for leather dust are not, and call into question the accuracy of the figure calculated by Slack.

While the inevitable shortcomings of our method are a source of uncertainty when estimating the absolute burden of mortality caused by work, the resultant biases are unlikely to have varied much over the 32-year period of study. Thus, we can be fairly confident that overall, excess mortality from the occupational hazards examined declined substantially in England and Wales between 1979 and 2010. For deaths from injury and poisoning, this conclusion is supported by other data collected independently. ${ }^{8}$ For some hazards, the fall in mortality has been a consequence of changing patterns of employment or a general reduction in mortality across all occupations. However, there is strong evidence also of improvements in safety.

The highest priority for future prevention of work-related fatalities is the minority of occupational disorders for which excess mortality remains static or is increasing. The continuing burden of disease caused by asbestos has been noted before, ${ }^{2}$ and patterns of risk by birth cohort, including for asbestosis, suggest that reductions in exposure to asbestos since the 1970s have brought benefits. ${ }^{12}$ However, there is still more to be achieved, with a special focus needed on certain trades in the construction industry. A useful starting point in planning further action might be to analyse patterns of incidence or mortality by birth cohort separately for relevant occupations. An absence of decline in recent birth cohorts would be a particular cause for concern. Also a priority is the persistent excess of sinonasal cancer in woodworkers. This was highlighted in our previous report, and data for the most recent 10 -year period again show no improvement. It is a well-established hazard, and should be manageable through controls on exposure to hardwood dust, particularly in the furniture industry.

Acknowledgements We thank the staff of the Office for National Statistics, who provided us with the data files for our analysis, and Stefania d'Angelo, who helped with part of the statistical analysis.

Contributors ECH contributed to the design of the study, jointly carried out the statistical analysis and jointly wrote the first draft of the paper. KTP contributed to the design of the study and to revision of the draft paper. VC jointly carried out the statistical analysis and contributed to revision of the draft paper. $A D$ and JO contributed to the design of the study and to revision of the draft paper. DC led the design of the study, oversaw the statistical analysis, and jointly wrote the first draft of the paper.

Funding Medical Research Council. 10.13039/5011000002 65. MRC_MC_UP_A620_1018. MRC_MC_UU_12011/5.

Competing interests None declared.

Provenance and peer review Not commissioned; externally peer reviewed.

Data sharing statement Data used in the analysis can be made available to other researchers subject to agreement from the Office for National Statistics.

\section{REFERENCES}

1 't Mannetje A, Pearce N. Occupational mortality studies: still relevant in the 21st century. Occup Environ Med 2010;67:802-3.

2 Coggon D, Harris EC, Brown T, et al. Work-related mortality in England and Wales, 1979-2000. Occup Environ Med 2010;67:816-22.

3 Vyas MV, Garg AX, lansavichus AV, et al. Shift work and vascular events: systematic review and meta-analysis. BMJ 2012;345:e4800.

4 Glozier N, Tofler GH, Colquhoun DM, et al. Psychosocial risk factors for coronary heart disease. Med J Aust 2013;199:179-80.

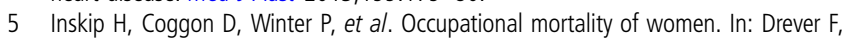
ed. Occupational health: decennial supplement. London: HMSO, 1995:44-61.

6 Newhouse ML, Berry G, Wagner JC. Mortality of factory workers in east London 1933-80. Br J Indust Med 1985;42:4-11.

7 Swift B, West K. Death certification: an audit of practice entering the 21 st century. J Clin Pathol 2002:55:275-9.

8 Health and Safety Executive. Statistics on fatal injuries in the workplace in Great Britain, 2015. http://www.hse.gov.uk/statistics/pdf/fatalinjuries.pdf

9 Alderson MR. Some sources of error in British occupational mortality data. Br J Indust Med 1972;29:245-54.

10 Rake C, Gilham C, Hatch J, et al. Occupational, domestic and environmental mesothelioma risks in the British population: a case-control study. Br J Cancer 2009;100:1175-83.

11 Slack R, Young C, Rushton L, British Occupational Cancer Burden Study Group. Occupational cancer in Britain: nasopharynx and sinonasal cancers. $\mathrm{Br} J$ Cancer 2012;107(Suppl):S49-55.

12 Darnton A, Hodgson J, Benson $\mathrm{P}$, et al. Mortality from asbestosis and mesothelioma in Britain by birth cohort. Occup Med 2012;62:549-52. 